\title{
Editorial: Greek Democracy, Old and New
}

Nea Demokratia (New Democracy) is the name of one of the two main political parties in Greece. Apparently new democracy means that the electorate should not be consulted on issues that bind ordinary people financially and politically to a system or decision they may well not want. In the case in question, it is a financial bail-out package designed to keep Greece in the European single currency, known as the Euro. Indeed many Greeks had been on the streets rioting to make the point that they were thoroughly fed up with being forced by Europe to adopt austerity measures in part designed to keep them in the Euro. But when the ruling party of the day proposed a referendum on the bail-out package, Nea Demokratia (the party which had actually been responsible for many of Greece's current Europe-related woes) strongly opposed it.

So, needless to say, did Europe's ruling elites, including the democratically elected leaders of Germany and France. No surprise there. The normal reaction of 'Europe' when faced with a bureacratically 'irritating' vote from one of its member states, is to tell them to vote again, and to make sure that they get the decision right next time. More often, as in Britain, the people are never allowed votes on European matters at all, in case, as they probably would, they go 'wrong'.

One of the objections of those against a Greek referendum was to say that those who might vote 'no' were not clear about what it was they might want instead. Indeed many of those who are vociferously opposed to current fiscal and financial arrangements more generally do not know what they want (apart from being 'against capitalism'). This not knowing what they want was actually seen by some commentators as to the credit of the tented protesters who started camping outside London's St Paul's Cathedral in October 2011. It was said that this protest might be the start of something new, a grand and enlightening conversation on the road to a better order. We need not deny all sympathy to objectors simply on the grounds that they do not know precisely what they want, given that there is little sign that the political elites in Europe and elsewhere (who at one level certainly do know what they want) actually know what they are doing, or have had any real sense of the consequences of their policies. 


\section{Editorial}

Old democracy (Athenian style) would have had no truck with any of this. The Athenian assembly was open to all entitled to vote (and on occasion up to $15 \%$ actually attended), and the council, which oversaw everything which came to the assembly, consisted of 500 (initially unpaid) citizens, chosen annually by lot and no one could serve on it more than twice. They did things differently then, though with modern means of communication an analogous system might not be too difficult to devise in 2012. To those frustrated people on the streets and to those favouring European referenda, there could be a lot to be said for a move to something like the old Athenian system. Maybe it is time for a new political party, to be known as Archaia Demokratia (old democracy), to pave the way for what, among other things, would mean the demise of political parties as we know them today. But, as philosophers, it would no doubt be incumbent on us to remind today's old democrats that not all the philosophers who knew it at first hand were entirely happy with old democracy. 